\title{
Undervisning för hållbar utveckling: att stödja högskolelärares arbete med Agenda 2030
}

\author{
Christel Persson ${ }^{a *}$, Maria Melén ${ }^{\mathrm{b}}$ och Daniel Einarson ${ }^{\mathrm{a}}$

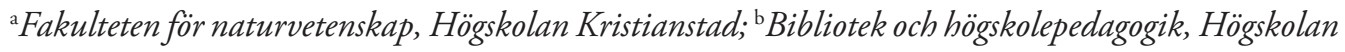 \\ Kristianstad
}

\begin{abstract}
Enligt Högskolelagen skall högskolorna i sin verksamhet främja en hållbar utveckling. FNs Agenda 2030 och dess 17 globala hållbarhetsmål belyser ytterligare högskolornas roll att utveckla och sprida kunskap om hållbar utveckling. Det ställs dock krav på högskolelärares insikter kring hållbarhetsbegreppet och iscensättandet av dess flervetenskaplighet $\mathrm{i}$ undervisningssituationen. Den här artikeln beskriver en fakultetsövergripande högskolepedagogisk kurs, Undervisning för hållbar utveckling, med dessa krav som utgångspunkt. Kursens genomförande och design presenteras, liksom syfte och lärdomar.
\end{abstract}

Nyckelord: Agenda 2030, "educate the educators", globala hållbarhetsmålen, högskolelärare, högskolepedagogisk utveckling, interdisciplinärt och tvärvetenskapligt förhållningssätt

\section{INLEDNING OCH BAKGRUND}

Hur kan arbetet med de 17 globala hållbarhetsmålen (se figur I), Agenda 2030, påverka och stimulera lärande för hållbar utveckling vid svenska lärosäten? Högre utbildnings roll är mycket betydelsefull när det gäller att ge studenterna grundverktygen för att i sitt framtida privat- och yrkesliv ta itu med frågor gällande en hållbar utveckling. För att studenter i högre utbildning utifrån olika utbildningsområden ska rustas för att integrera sådana frågor, samt möjliggöra förmågan att reflektera kring dem, behöver ett angreppssätt som tar sin utgångspunkt i deras lärande arbetas fram.

Med anledning av ovanstående har det vid Högskolan Kristianstad startats ett utvecklingsarbete. Det är centrerat kring en högskolepedagogisk kurs för högskolelärare i syfte att utveckla insikter om och färdigheter i undervisning för hållbar utveckling (HU). Kursen hålls fakultetsövergripande, vilket innebär ett fundament för tvärdisciplinära diskussioner.

Hållbar utveckling kräver ur ett utbildningsperspektiv såväl detaljerad kunskap om ekologi, ekonomi, politik och samhälle som en helhetssyn. De globala hållbarhetsmålen innehåller dimensioner om fattigdom, hälsa, utbildning och vattenförsörjning såväl som om demokrati- och jämställdhetsdimensioner. Samarbetet mellan de olika vetenskapliga disciplinerna är önskvärt och i det spelar medvetandegörandet hos universitets- och högskolelärare en stor roll.

Universitets- och högskoleutbildning har ett stort inflytande genom att t.ex. utbilda sjuksköterskor, ekonomer, lärare och ingenjörer. Högre utbildning kan på så sätt ses som den förlängda armen till det omgivande samhället.

*Författarkontakt: christel.persson@hkr.se mons Attribution-NonCommercial 4.0 International License (https://creativecommons.org/licenses/by-nc/4.0/), allowing third parties to share their work (copy, distribute, transmit) and to adapt it, under the condition that the authors are given credit, that the work is not used for commercial purposes, and that in the event of reuse or distribution, the terms of this license are made clear

Citation: Christel Persson, Maria Melén \& Daniel Einarson (2020) «Undervisning för hållbar utveckling: att stödja högskolelärares arbete med Agenda 2030", Högre utbildning, 10(1), 18-24. https://doi.org/10.23865/hu.v10.1949 


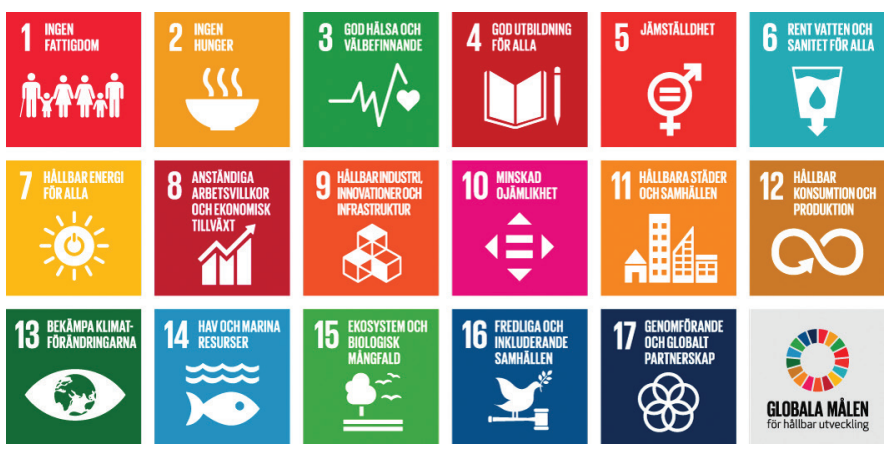

Figur I. FN:s globala hållbarhetsmål (United Nations, 20I5).

Enligt högskolelagen (Högskolelagen, 2005:I208, $\$ 5$ ) är uppdraget att: "Högskolorna skall i sin verksamhet främja en hållbar utveckling som innebär att nuvarande och kommande generationer tillförsäkras en hälsosam och god miljö, ekonomisk och social välfärd och rättvisa”, vilket i sig kan ses som vilande på Brundtlandkommissionens rapport (Brundtlandkommissionen, 1987). Universitetskanslersämbetet (UKÄ) är den instans i Sverige som har som uppgift att övervaka att lärosätena efterföljer högskolelagen, och genomförde därför 2017 en tematisk utvärdering angående obligatoriet gällande $\mathrm{HU}$ vid lärosätena. Generellt sett synliggjorde utvärderingen att flertalet av lärosätena inte levde upp till högskolelagens intentioner i sitt arbete med hållbar utveckling (Universitetskanslersämbetet, 20I8). Vid ett återkopplingsmöte mellan lärosätena och UKÄ framkom dock att flera av lärosätena upplevde en osäkerhet kring arbetet med HU och till följd därav av vad som skulle utvärderas. Som ett resultat av återkopplingen gavs en muntlig rekommendation om att framgent använda de 17 globala målen som utgångspunkt i arbetet.

Levi och Rothstein (20I8) motiverar akademins signifikanta roll som bidragande till HU genom sina studenter. Akademin bör enligt författarna välja en tydlig aktörsroll för att kunna ta den ledande rollen i arbetet att förmedla kunskaper om strävan efter ett hållbart samhälle. Vidare poängteras att de globala målen ska ses som en tvärvetenskaplig helhet och varnar därför för ett silo-seende kring enskilda specialiserade ämnesområden.

Ovanstående diskussioner motiverar att

I) lärosätena behöver utbilda studenter i HU

2) lärarna på lärosätena behöver utbildas i HU för att i sin tur kunna utveckla studenternas värdefulla kompetenser inom $\mathrm{HU}$

3) lärarna dessutom behöver stöd i att se på $\mathrm{HU}$ ur interdisciplinära perspektiv.

Den aktuella högskolepedagogiska kursen, vars innehåll och genomförande kommer att beskrivas, är därmed motiverat.

\section{KURSUTVECKLINGENS KONTEXT OCH DESIGN}

Lärosätet har ambitionen att vara en naturlig motor för omgivningen avseende utvecklandet av innovations- och hållbarhetskompetens. Men kunskapen om och förmågan att agera med sikte på uppnåendet av hållbarhetsmålen får anses vara relativt ny och utmanande och behöver utvecklas i takt med hållbarhetsfrågorna. Ledning, högskolelärare och studenter utgör tre 
viktiga nivåer vid implementering och integrering av lärosäteskompetens avseende HU. I den här texten är det högskolelärarens kompetens och förhållningssätt som står i fokus.

Bakom kursens tillkomst ligger ett identifierat behov vid lärosätet av att rusta läraren i att kunskapsmässigt integrera ett hållbarhetsperspektiv i undervisningen. Samtidigt är det viktigt att se undervisningen för HU som ett i sig viktigt lärtillfälle att utveckla studenters handlingsberedskap och på ett autentiskt sätt träna dem i att inta rollen som aktörer i uppnåendet av HU. Lärosätet har en idé om att studenten genom undervisningsdesignen ska uppnå såväl ämneskunskaper som handlingsberedskap, så kallade nyckelkompetenser avseende HU (samma uppfattning presenteras av Wiek, Withycombe \& Redman, 20II). Vi utgår från att det kan skapa goda förutsättningar för ett hållbart och därmed livslångt lärande och aktiva lärandeformer förknippas med utvecklingen av nyckelkompetenser (Lozano, Barreiro-Gen, Lozano \& Sammalisto, 2019; United Nations Educational, Scientific and Cultural Organization, UNESCO, 20I7). Kursen syftar således till att möjliggöra för högskoleläraren att bli varse om att såväl innehåll som pedagogiskt förhållningssätt har bäring på studenters utvecklande av kunskaper och färdigheter avseende HU.

Lozano (2006) framhåller att högskolelärarens höga grad av specialisering inom sitt ämnesområde och utbildningarnas innehållsmässiga uppbyggnad mot ett specifikt ämnesområde gör att studenten erövrar omfattande kunskap om ett ämne och utvecklar färdigheter och förmågor att agera inom ramen för detta. Studenten behöver dock också kunna se att effekten av det egna agerandet kan tolkas olika, avhängigt vilka glasögon gällande ämnesområdet betraktaren bär, som en förutsättning för uppnåendet av HU givet hållbarhetsmålen i Agenda 2030. En utgångspunkt med kursen är därför att högskoleläraren får stöd i att integrera HU med det egna ämnesområdet. En ökad medvetenhet om hur den egna undervisningspraktiken ser ut möjliggör studentens utvecklande av hållbarhetskompetens. Därmed ges studenten förutsättningar att bli en förändringsagent.

Det finns sedan tidigare ett antal exempel på framgångskoncept vid utformningen av kurser för lärare inom högre utbildning med tvärvetenskapliga deltagargrupper som en resurs och som en förutsättning för integrering av hållbarhetsperspektiv, educate-the-educator course (Lozano-García et al., 2008). En annan erfarenhet och utgångspunkt vid förändringsarbete i organisationer är att använda och arbeta utifrån förebilder eller goda exempel, jämför Appreciative inquiry (Cooperrider \& Whitney, 2005). Vid designen av kursen Undervisning för hållbar utveckling tillvaratogs dessa utgångspunkter genom att kollegor i egenskap av högskolelärare och forskare vid lärosätet bjöds in och delade med sig av sina specifika undervisningserfarenheter inom hållbarhetsområdet.

\section{ISCENSÄTTANDE OCH GENOMFÖRANDE AV DEN HÖGSKOLEPEDAGOGISKA KURSEN}

Kursinnehållet med kopplingar till kursmålen består i att synliggöra och diskutera innebörden av begreppet HU i ämnesutvecklingen och konkretisera hur detta kan avspeglas i utbildningssammanhang. Kursens kärna är att i befintliga kurser designa kursmål, lärandeaktiviteter och examination med uppföljning relevant för HU.

Is kursdeltagare från lärosätet deltog i fem undervisningsdagar där det avslutande kurstillfället präglades av examinationsuppgiftens muntliga redovisningar. Kursdeltagarnas fakultetstillhörighet var hälsovetenskap, lärarutbildning, naturvetenskap.

Under kursdagarna mötte kursdeltagarna inbjudna gästföreläsare från ämnesdisciplinerna ekologi, ekonomi, hälsa, gastronomi och sociologi för att delges kunskap och förståelse för 
olika angreppssätt och perspektiv på begreppet HU. Hur de globala hållbarhetsmålen är relevanta för gästföreläsarnas respektive ämnesområden presenterades och kopplades samman med såväl forsknings- som undervisningstraditioner över tid. Mellan träffarna förväntades kursdeltagarna ta del av rekommenderad litteratur och formulera en plan att ta sig an förestående examinationsuppgift. Den digitala lärplattformen utgjorde en viktig del i lärandeprocessen då den innehöll en läranderesursmapp med bl.a. vetenskapliga artiklar, Youtube-klipp och debattartiklar. Läranderesursmappen utformades tillsammans med kursdeltagarna utefter intresse och behov och med lärandemålen som ledstjärna.

Examinationsuppgiftens övergripande syfte är att kursdeltagaren i rollen som högskolelärare förändrar och utvecklar såväl kursinnehåll som genomförandet givet hållbarhetsperspektivet i sina kurser. Dessutom examineras ett metaperspektiv i form av att reflektera över och beskriva hur en ämnesintegrering är möjlig att formas med de $\mathrm{I} 7$ globala hållbarhetsmålen som utgångspunkt.

Målet för den muntliga examinationsdelen är att tillsammans med kursgruppen praktiskt genomföra en lärandeaktivitet med hållbarhetsfokus. Kursdeltagaren ger inledningsvis en kort presentation av en planerad praktisk lärandeaktivitet. Ett av kursmålen för den här aktuella högskolepedagogiska kursen formuleras enligt följande: "Visa förmåga att driva och ta ansvar för den egna kompetensutvecklingen inom området för hållbar utveckling", vilket i sammanhanget visar väl på ett erfarenhetsutbyte av varandras repertoar av pedagogiska metoder för handlingsberedskap.

Under det muntliga examinationstillfället, likställt ett lärandetillfälle, gavs kursdeltagarna möjligheten att diskutera och kritiskt utveckla sina tankar samt reflektera kring begreppet hållbarhet $\mathrm{i}$ relation till det egna undervisningsområdet med koppling till lärar- och yrkesrollen.

I den skriftliga examinationsdelen beskrevs på ett fördjupande sätt den "nydesignade" lärandeaktivitetens tillämpning i förhållande till lärandemål, kursmål och de 17 globala hållbarhetsmålen. Även kritiska resonemang avseende hållbarhet i termer av studentcentrerat lärande, demokrati-, hälso-, jämlikhethets-, ekonomi-, ekologi- och utbildningsbegreppen samt lärandeerfarenheter från den aktuella kursen togs upp.

\section{BEARBETNING AV DATA OCH ANALYSFÖRFARANDE}

Ett huvudsyfte med kursen har varit att ge lärarna vid lärosätet en möjlighet att integrera HU i sin undervisning, särskilt med utgångspunkt i FNs globala hållbarhetsmål. Högskoleläraren behöver ha en förståelse kring hur

I) kursinnehåll och undervisningsmoment exemplifierar $\mathrm{HU}$

2) det går att iscensätta lärandeaktiviteter utifrån ett studentcentrerat förhållningssätt

3) mångfalden i de $I 7$ globala målen är tvärvetenskaplig. Därför bör specialkompetensen hos den enskilde läraren utgöra en utgångspunkt till det särskilda undervisningsområdets påverkan på andra samhällsfenomen snarare än till silo-orientering.

Kursdeltagarnas prestationer och reflektioner som beskrivs i resultatdelen är av övergripande art och forskningsetiska riktlinjer har följts (Vetenskapsrådet, 20I7).

\section{KURSKONCEPTETS RESULTAT}

Kursdeltagarnas presentationer visar generellt på en ökad medvetenhet om det egna undervisningsområdet i relation till $\mathrm{HU}$. De konstaterar att $\mathrm{HU}$ behandlas i kurser men att de hittills 
själva saknat begrepp och därför är detta inte tillräckligt tydligt uttryckt i kursplaner och lärandemål, vilket också framkom i UKÄ:s tematiska utvärdering. Därmed blir det otydligt för studenten att det är HU som behandlas. Kursdeltagarna vittnar om att de med enkla medel kan förtydliga sådana undervisningsmoment.

I kursdeltagarnas material ges beskrivningar av ett begränsat utrymme för studenten att utveckla ett kritiskt förhållningssätt och aktörskap, dvs. handlingsberedskap. Flera exempel tyder på att en vanlig undervisningsform består i att läraren överför teoretiska kunskaper till studenterna i form av storföreläsningar. Studenterna kan ses som mottagare av information. Genom att istället ge studenterna möjligheter att associera till vad t.ex. innebörden av $\mathrm{HU}$ betyder och är för dem, samt självständigt reflektera kring olika begrepps innebörd, anger kursdeltagarna att studenternas lärande kan bli mer aktivt. Nedan följer några exempel på kursdeltagarnas utveckling av lärandeaktiviteter med studenterna.

Ett vanligt förekommande inslag som beskrivs är problematiseringsövningar gällande vattenfrågor där ett flertal hållbarhetsmål berörs. Studenterna ges i uppgift att komma med förslag på framtidsfokuserade hållbara lösningar. För att främja handlingsberedskap och innovation diskuteras markvårdsåtgärder för säkring av färskvattenresurser, teknikutveckling för avsaltning av havsvatten liksom teknik för att återanvända avloppsvatten.

Att utveckla studentens idé- och kreativitetsförmåga kan också ske genom att ge studenterna i uppgift att formulera och konkretisera en progression av hur begreppet empati kan behandlas redan tillsammans med de yngre barnen i förskolan (Steg I och 2).

Steg I: Bli medveten om och hantera sina egna känslor

Steg 2: Förstå andras känslor och att alla inte känner likadant

Detta ger förutsättningar för att respektera andras sätt att känna. Tanken är att studenterna ska utmanas i att själva uppfinna lärandeaktiviteter i lärandet för hållbar utveckling anpassade för barnens olika åldrar.

Lärandeaktiviteterna som beskrevs under det muntliga examinationstillfället hade också ett fokus på studenternas kommande yrkesgärning. En ögonöppnare gällande det tvärvetenskapliga förhållningssättet beskrivs särskilt exemplariskt av en kursdeltagare. Det tidigare så självklara hållbarhetsmålet God hälsa och välbefinnande där tillgång till läkemedel tas för givet ställs i konflikt med målet Hav och marina resurser, eftersom läkemedelsrester hamnar i sjöar och vattendrag. Ett holistiskt synsätt träder fram.

Till de konkreta exemplen kan också en rollspelsaktivitet i form av ett fiktivt lokalt planeringsmöte om vindkraftsutveckling lyftas fram. Rollerna som studenterna företrädde var bl.a. exploatörer, boende, markägare, politiker, samtalsledare med fokus på att praktiskt tillämpa och diskutera olika kommunikationsstrategier från kursens teoretiska horisont.

I övningarna testade samtalsparterna praktiskt effekter av distans och närhet gällande att ge eller inte ge feedback. Lyssnande och metakommunikation, dvs. att under samtalets gång synliggöra hur samtalsaktörerna talar med varandra, synliggjordes och reflekterades. Exemplet relateras till hållbarhetsmålen Hållbar energi och Hållbar produktion och konsumtion.

\section{DISKUSSION OCH SLUTSATS}

Resultatet blev utifrån kursledningens perspektiv över förväntan. En uppföljning pågår gällande hur lärarna (dvs. kursdeltagarna) med inspiration från kursexaminationen har implementerat hållbarhetsaspekter i undervisning och kursplaner. Uppföljningen innefattar dels en genomgång 
och sammanställning av examinationsuppgifter från kursen, dels fokusgruppsintervjuer med de lärare som har gått kursen. Frågor som fördjupas är exempelvis: Har kursplaner omarbetats avseende hållbarhetsaspekter och de globala hållbarhetsmålen och i så fall på vilket sätt? Hur sker kommunikationen med studenterna om hållbarhetsfrågor idag jämfört med tidigare? Vilka lärdomar om hållbarhet bär lärarna med sig efter genomgängen kurs?

En utmaning för framtiden är att utveckla en pedagogisk modell när det gäller att undervisa över ämnesgränserna (ämnesintegrering) med det livslånga lärandet som en av ledstjärnorna. Erfarenheter från uppföljningen kommer förhoppningsvis att utgöra ett värdefullt resursmaterial för det fortsatta arbetet med att integrera hållbarhetsaspekter i utbildningar vid lärosätet.

\section{FÖRFATTARPRESENTATION}

Christel Persson är docent i naturvetenskapernas didaktik med inriktning mot hållbar utveckling. Hon är verksam inom Fakulteten för naturvetenskap vid Högskolan Kristianstad och hennes forskningsfokus utgörs bl.a. av System Jorden (Earth System Science) som ett pedagogiskt verktyg för undervisning inom hållbar utveckling på universitets- och högskolenivå. Hon har också författat läroböcker inom miljövetenskap och hållbar utveckling.

Maria Melén är fil.dr i psykologi och arbetar som högskolepedagogisk utvecklare vid Högskolan Kristianstad. Inom ramen för det arbetet är uppgiften att initiera olika kompetensutvecklande insatser för Högskolans chefer och medarbetare. Maria är ledamot av både Högskolans pedagogiska akademi och ledarskapsakademi vars uppdrag är att driva utveckling vid lärosätet.

Daniel Einarson är universitetslektor i datavetenskap vid Fakulteten för naturvetenskap, Högskolan Kristianstad. Han har särskilt drivit utvecklingen för inrättandet av det internationella magisterprogrammet i datavetenskap med fokus på hållbar utveckling. Inom detta program agerar han inom flera kurser och bjuder bl.a. in studenter att medverka i forskningsprojekt med hållbarhetsfokus. Det handlar exempelvis om användande av maskininlärning för studier av vattenkvalitet.

\section{REFERENSER}

Brundtlandkommissionen. (1987). Our common future. Stockholm.

Cooperrider, D. \& Whitney, D. D. (2005). Appreciative inquiry. Oakland CA: Berrett-Koehler Publishers. Högskolelagen 2005:1208, \$5. Stockholm: Högskoleverket.

Levi, L. \& Rothstein, B. (2018). Universities must lead on sustainable development goals, University World News, 2018-11-09. Hämtad 2019-09-22, från https://www.universityworldnews.com/post.php? story $=20181106131352348$

Lozano, R. (2006). Incorporation and institutionalization of SD into universities: breaking through barriers to change. Journal of Cleaner Production, 14(9), 787-796.

Lozano, R., Barreiro-Gen, M., Lozano, F. J., \& Sammalisto, K. (2019). Teaching sustainability in European higher education institutions: Assessing the connections between competences and pedagogical approaches. Sustainability, 11(6), 1602.

Lozano-García, F. J., Gándara, G., Perrni, O., Manzano, M., Elia Hernández, D. \& Huisingh, D. (2008). Capacity building: a course on sustainable development to educate the educators. International Journal of Sustainability in Higher Education, 9(3), 257-281.

United Nations. (2015). Transforming our world: the 2030 Agenda for Sustainable Development. New York: United Nations.

United Nations Educational, Scientific and Cultural Organization, UNESCO. (2017). Education for sustainable development goals: Learning objectives. Paris, FR: UNESCO. Hämtad 2020-03-04 från https://unesdoc.unesco.org/ark:/48223/pf0000247444 


\section{Christel Persson et al.}

Universitetskanslersämbetet. (2018). Utvärdering av arbetet med att främja hållbar utveckling. Stockholm: UKÄ. Hämtad 2019-09-22, från https://www.uka.se/publikationer--beslut/publikationer--beslut/ beslut-tematiska-utvarderingar/tematiska-utvarderingar/2017-10-02-utvardering-av-arbetet-medatt-framja-hallbar-utveckling.html

Vetenskapsrådet. (2017). God forskningssed. Hämtad 2019-09-30 från https://www.vr.se/analys-och-uppdrag/vi-analyserar-och-utvarderar/alla-publikationer/publikationer/2017-08-29-god-forskningssed. html

Wiek, A., Withycombe, L. \& Redman, C. L. (2011). Key competencies in sustainability: a reference framework for academic program development. Sustainability Science, 6(2), 203-218. 